\title{
Correction to: A four-step mutation at D22S1045 in one complex paternity case when the brother of the alleged father hypothesis is evaluated
}

\author{
Lizbeth J. González-Herrera ${ }^{1}$ • Mayra E. García-Aceves ${ }^{2}$ • Martin D. Domínguez-Cruz ${ }^{3}$ • Paola N. López-González ${ }^{4}$. \\ Javier E. Sosa-Escalante ${ }^{4} \cdot$ Héctor Rangel-Villalobos $^{2}$
}

Published online: 5 June 2020

(C) Springer-Verlag GmbH Germany, part of Springer Nature 2020

Correction to: International Journal of Legal Medicine (2020)

https://doi.org/10.1007/s00414-020-02312-1

This article was published online with an error. Given names and family names of the authors were interchanged. The correct author names are presented above. The original article has been corrected.

Publisher's note Springer Nature remains neutral with regard to jurisdictional claims in published maps and institutional affiliations.

The online version of the original article can be found at https://doi.org/ 10.1007/s00414-020-02312-1

Héctor Rangel-Villalobos

hrangel13@hotmail.com

1 Centro de Investigaciones Regionales, Universidad Autónoma deYucatán (UADY), Mérida, Yucatán, Mexico

2 Instituto de Investigación en Genética Molecular, Centro Universitario de la Ciénega, Universidad de Guadalajara, (CUCiénega-UdeG), Av. Universidad \#1115, Col. Paso Blanco, CP 47810 Ocotlán, Jalisco, Mexico

3 Laboratorio de Genética del Instituto Jalisciense de Ciencias, Forenses (IJCF), Guadalajara, Jalisco, Mexico

4 DIMYGEN Laboratorio S.C.P., Mérida, Yucatán, Mexico 